\title{
Ganglioside GQ
}

National Cancer Institute

\section{Source}

National Cancer Institute. Ganglioside GQ. NCI Thesaurus. Code C104201.

A sialoglycosphing olipid that is a branched nonasaccharide containing five sialyl residues, two galactose residues, one $\mathrm{N}$-acetylg alactosamine residue and a glucose residue. This ceramide is found associated with the surface of the plasma membrane in developing thymic epithelial cells, oligodendrocyte progenitors, neuroendocrine cells, neurons and neuroblastoma cells. 